\title{
"DIABETIC RETINOPATHY - KNOWLEDGE, ATTITUDE AND PRACTICES (KAP) IN DIABETIC PATIENTS ADMITTED IN TERTIARY CARE CENTERS OF PESHAWAR - KHYBER PAKHTUNKHWA".
}

1. MBBS, MPH

Assistant Professor

Department of Community Medicine Rehman Medical College, Peshawar.

2. Student of Final Year MBBS

Rehman Medical College, Peshawar.

3. Student of Final Year MBBS

Rehman Medical College, Peshawar.

4. Student of Final Year MBBS

Rehman Medical College, Peshawar.

5. Student of Final Year MBBS

Rehman Medical College, Peshawar.

Correspondence Address:

Dr. Ali Raza

Department of Community Medicine Rehman Medical College, Peshawar. doctor.raza@hotmail.com

Article received on:

10/06/2019

Accepted for publication:

20/07/2019

Received after proof reading:

$31 / 07 / 2019$
Ali Raza1, Izma Khan², Haider Sami ${ }^{3}$, Amna Ejaz ${ }^{4}$, Zunnoor Ahmed ${ }^{5}$

ABSTRACT... Introduction: Diabetes Mellitus is a metabolic disorder which occurs due to the deficiency of insulin and results in increased blood glucose levels. Diabetic Retinopathy is a major complication of diabetes which can lead to blindness. Objectives: To assess the knowledge, attitude and practices regarding Diabetic Retinopathy in diabetic patients admitted in tertiary care centers of Peshawar. Study Design: Cross sectional study. Setting: Medical and Surgical wards of Rehman Medical Institute and Hayatabad Medical Complex, Peshawar. Period: December 2016 to April 2017. Materials and Methods: 351 patients admitted in medical and surgical wards of Rehman Medical Institute and Hayatabad Medical Complex, Peshawar. Diabetics were selected by convenience sampling technique and data were collected through interview based questionnaire. Result: The study included 351 patients, $65.2 \%$ were males and $34.8 \%$ females. Average age was 52 years with $76 \%$ of the respondents having positive family history and $66 \%$ having diabetes from the last 10 years. $87.2 \%$ agreed that diabetes can cause diabetic retinopathy. The mean knowledge score was 13.48 . Knowledge was significantly associated with education levels and male gender with $\mathrm{P}<0.001$ and 0.02 respectively. The correlation analysis between knowledge and attitude showed weak negative but significant relationship with $\mathrm{P}<0.002$. $80.9 \%$ agreed that diabetic retinopathy can be prevented if diabetes is controlled early on, with only $30 \%$ getting their check up on annual basis and 26.5 $\%$ on bi annual basis. Conclusion: Mass awareness campaigns using population and high risk strategies as a primary prevention is need of the hour. Illiterates and women are more susceptible to the complication of diabetes in particular diabetic retinopathy. Involvement of general physicians and ophthalmologists for susceptible patient screening is recommended in the light of this study.

Key words: $\quad$ Awareness, Diabetes, Diabetic Retinopathy, Diabetic Complications, Knowledge.

Article Citation: Raza A, Khan I, Sami H, Ejaz A, Ahmed Z. "Diabetic retinopathy knowledge, attitude and practices (KAP) in diabetic patients admitted in Tertiary Care Centers of Peshawar - Khyber Pakhtunkhwa". Professional Med J 2019; 26(8):1370-1376. DOI: 10.29309/TPMJ/2019.26.08.3805

\section{INTRODUCTION}

Diabetes Mellitus is a chronic metabolic disorder in which there is a decrease production of insulin by the pancreas or decreased effectiveness of the insulin produced. This results in increased blood glucose levels. ${ }^{1}$ The increased blood glucose levels hinder with the normal functioning of tissue organs of the body causing both micro and macro vascular complication. Small vessels that supply organs are effected more and hence, contribute to the various micro vascular complications (retinopathy, neuropathy and nephropathy) caused by diabetes.
During the past decade, there has been a drastic rise in prevalence of diabetes globally. The total number of diabetics worldwide is expected to rise from 171 million in 2010 to 366 million in $2030{ }^{2}$

According to International Diabetes Federation (IDF), the total number of diabetics in Pakistan is expected to rise from 6.6 million to 14.5 million by year $2025 .^{3}$ If preventive and policy measures are not taken timely; it is predicted that Pakistan will have fourth largest diabetic population by 2025 .

A major complication of Diabetes is Diabetic Retinopathy (DR). It is the leading cause of 
blindness among working age population around the world. The disease primarily effects the blood vessels of retina. ${ }^{4,5}$ In 2010, among 285 million cases of diabetes, over $1 / 3^{\text {rd }}$ reported signs of diabetic retinopathy. ${ }^{6}$ Older age, male, gender, family history, hypertension, hyperglycemia and smoking are significantly linked with the incidence of retinopathy in type 2 diabetic patients. ${ }^{7}$ If timely and effective management is provided, present treatment options can prevent as much as 98 $\%$ of visual complications because of diabetic retinopathy. ${ }^{6}$

To create awareness among the community, it is important to know the extent of their knowledge, attitudes and practices about diabetes and diabetic retinopathy. ${ }^{5}$

In a KAP study in Saudi Arabia, $75.6 \%$ patients were aware that diabetes can cause eye disorders, and about $95 \%$ of all the participants went for regular ocular examinations. ${ }^{7}$

In a study in U.S 55.3\% adults of age 40 and above with diabetic macular edema reported that they had not been informed by a doctor that they had retinopathy. $46.7 \%$ reported they had not been to a diabetes nurse educator, dietician or nutritionist for their diabetes and $39.3 \%$ did not receive an eye exam in the last year. ${ }^{6}$

In a South Indian Study, good knowledge was observed in $40.7 \%$ diabetics, and $57.6 \%$ had good practice patterns but only $9.6 \%$ had screening for retinopathy. The study showed that education was associated with higher KAP scores about diabetes and diabetic retinopathy. ${ }^{8}$ In another study in South Africa the majority of the respondents had poor practice of annual eye checkups and $24 \%$ believed that diabetes can be cured. ${ }^{9}$

In a study done in Karachi, 48.12\% were totally unaware about diabetes. Among the remaining approximately half of the respondents; $30 \%$ failed to show any knowledge of various aspects of diabetes. $70 \%$ had some knowledge about clinical and scientific aspects of the disease. ${ }^{5}$

\section{RATIONALE OF STUDY}

There is a prominent rise in the occurrence of diabetes in Pakistan which is resulting in severe complications such as diabetic retinopathy. The purpose of this study is to know about the awareness and practice patterns of diabetic patients about diabetic retinopathy. This could guide the implementation of strategies to reduce the prevalence and severity of ocular complications.

\section{OBJECTIVES}

The objectives of this study are to assess the knowledge, attitude and practices of diabetics regarding Diabetic Retinopathy in patients admitted in tertiary care public and private hospitals of Peshawar.

\section{MATERIALS AND METHODS}

The comparative cross sectional study was conducted on diabetic patients in medical and surgical wards of Rehman Medical Institute (RMI) and Hayatabad Medical Complex (HMC) from December 2016 to April 2017. Public and private health facilities were selected in order to minimize the bias due to socio-economic status. The calculated sample size was 351 , and data were collected by employing convenience sampling technique. Hospitalized adults with type 2 diabetes were included in the study. Patients less than 18 years of age, patients with type 1 , gestational or other types of diabetes, and those with eye problems were excluded from the study.

A structured closed ended questionnaire to assess the knowledge, attitude and practice of diabetic patients about diabetic retinopathy was used. A pilot study was conducted to test the validity of questionnaire. The questionnaire was approved by ophthalmologist and was translated into standard Pashto for patient's convenience. Informed consent was obtained from the patients. Patients' demographic and disease information data like age, gender, education level, time since diagnoses of diabetes, family history and source of diabetes information were incorporated in the questionnaire. Patients' response categories were in two formats; Binary (Yes - No) and three format (Agree, Uncertain and Disagree) items. For 
binary responses, each correct answer was given a score of "one" and wrong answer was scored as "zero". For other questions, agree had a score of 2, uncertain had a score of 1 and disagree was denoted with zero. 14 questions were aimed at assessing knowledge of the patients with 3 and 4 questions each to assess their attitude and practice.

Data were entered and analyzed using SPSS v.23. Descriptive statistics were used to study the characteristics of the study population. Categorical variables were presented as frequencies and percentages and their analysis were done using Chi-square test. Continuous variables were described as means and standard deviation and analysis was done using independent $t$ - test and one way ANOVA. A P- value of $<0.05$ was considered as statistically significant.

\section{RESULTS}

For data collection, 351 questionnaires were filled from diabetic patients admitted in medical and surgical wards of RMI (44.2\%) and HMC (55.8 $\%)$, Peshawar. Out 351 respondents, 229 (65.2\%) were males and 122 (34.8\%) were females. 86 $(24.5 \%)$ patients were in age group of $20-40$ years, 178 (50.7\%) in 41-60 years, and 87 (24.8 $\%)$ patients were in the age group of 60 years and above. $66 \%$ of the sample were diabetics from the last 10 years, $22.7 \%$ were having 11 to 20 years of duration of diabetes followed by $11.1 \%$ of the sample with more than 20 years of duration of diabetes.

Regarding education level, $43.6 \%$ individuals were uneducated, $18.2 \%$ graduates and 14.5 $\%$ were post-graduates. Table-I summarizes the results.

Table-Il is showing frequencies of responses regarding knowledge of various risk factors for diabetic retinopathy. The frequency results show that the study sample had good knowledge about the risk factors for diabetic retinopathy. However, an independent $t$-test between knowledge and individuals' attitude regarding the same shows that uncontrolled sugar level, time duration of diabetes and elevated cholesterol levels did not statistically differ among the response groups with respect to their attitude. The remaining variables were significantly associated with attitude score. Table-II summarizes the association results.

\begin{tabular}{|c|c|c|c|}
\hline \multicolumn{2}{|c|}{ Variables } & \multirow{2}{*}{$\begin{array}{c}\mathbf{N} \\
196 \\
\end{array}$} & \multirow{2}{*}{$\begin{array}{c}\text { Percentage } \\
(\%)\end{array}$} \\
\hline Health & Public - HMC & & \\
\hline Facility & Private - RMI & 155 & 44.2 \\
\hline \multirow{2}{*}{ Gender } & Male & 229 & 65.2 \\
\hline & Female & 122 & 34.8 \\
\hline \multirow{3}{*}{$\begin{array}{l}\text { Age in } \\
\text { Categories }\end{array}$} & $20-40$ years & 86 & 24.5 \\
\hline & $41-60$ years & 178 & 50.7 \\
\hline & 60 years and above & 87 & 24.8 \\
\hline \multirow{2}{*}{$\begin{array}{l}\text { Family } \\
\text { History }\end{array}$} & Yes & 267 & 76.1 \\
\hline & No & 84 & 23.9 \\
\hline \multirow{4}{*}{$\begin{array}{l}\text { Time Since } \\
\text { Diagnosis } \\
\text { of Diabetes }\end{array}$} & $1-10$ years & 233 & 66 \\
\hline & $11-20$ years & 80 & 22.9 \\
\hline & 21 - 30 years & 33 & 9.6 \\
\hline & $31-40$ years & 5 & 1.5 \\
\hline \multirow{7}{*}{$\begin{array}{l}\text { Education } \\
\text { Level }\end{array}$} & Uneducated & 153 & 43.6 \\
\hline & Primary & 6 & 1.7 \\
\hline & Secondary & 13 & 3.7 \\
\hline & Matric & 40 & 11.4 \\
\hline & Intermediate & 24 & 6.8 \\
\hline & Graduate & 64 & 18.3 \\
\hline & Post - graduate & 51 & 14.5 \\
\hline
\end{tabular}

Table-I. Characteristics of the study sample

\begin{tabular}{|l|l|l|l|}
\hline Questions & Yes & No & P-Value \\
\hline
\end{tabular}

Knowledge of risk factors for diabetic retinopathy and its association with attitude score

\begin{tabular}{|l|c|c|c|}
\hline $\begin{array}{l}\text { Do you know that } \\
\text { diabetes can cause } \\
\text { diabetic retinopathy? }\end{array}$ & $\begin{array}{c}306 \\
(87.2 \%)\end{array}$ & $\begin{array}{c}45 \\
(12.8 \%)\end{array}$ & 0.02 \\
\hline Uncontrolled sugar level & $\begin{array}{c}314 \\
(89.5 \%)\end{array}$ & $\begin{array}{c}20 \\
(5.7 \%)\end{array}$ & 0.34 \\
\hline $\begin{array}{l}\text { More than 10 years of } \\
\text { Diabetes }\end{array}$ & $\begin{array}{c}256 \\
(72.9 \%)\end{array}$ & $\begin{array}{c}75 \\
(21.4 \%)\end{array}$ & 0.32 \\
\hline $\begin{array}{l}\text { Uncontrolled Blood } \\
\text { Pressure }\end{array}$ & $\begin{array}{c}242 \\
(68.9 \%)\end{array}$ & $\begin{array}{c}84 \\
(23.9 \%)\end{array}$ & 0.01 \\
\hline $\begin{array}{l}\text { Elevated Blood } \\
\text { Cholesterol }\end{array}$ & $\begin{array}{c}171 \\
(48.7 \%)\end{array}$ & $\begin{array}{c}148 \\
(42.2 \%)\end{array}$ & 0.37 \\
\hline Smoking & $\begin{array}{c}148 \\
(42.2 \%)\end{array}$ & $\begin{array}{c}173 \\
(49.3 \%)\end{array}$ & \begin{tabular}{c}
$\mathrm{P}$ \\
\hline 0.001
\end{tabular} \\
\hline Regular Exercise & $\begin{array}{c}42 \\
(12 \%)\end{array}$ & $\begin{array}{c}285 \\
(81.2 \%)\end{array}$ & $\begin{array}{c}\mathrm{P} \\
<0.001\end{array}$ \\
\hline
\end{tabular}

Table-II. Knowledge about risk factors for diabetic retinopathy and its association with attitude 
Similarly Table-III summarizes association of knowledge with individuals' attitude about treatment options available for diabetic retinopathy. The frequencies for various response categories are mentioned in the table. Overall, the patients had good knowledge regarding the general preventive measures, as compared to laser surgical and intra ocular injection treatments for diabetic retinopathy. The treatment options were statistically non-significant with respect to patient's attitude.

Association of Attitude with Knowledge regarding Treatment Options For Diabetic Retinopathy

\begin{tabular}{|c|c|c|c|c|}
\hline & Agree & Uncertain & Disagree & P-Value \\
\hline $\begin{array}{l}\text { No treatment } \\
\text { Available }\end{array}$ & $\begin{array}{c}58 \\
(16.5 \%)\end{array}$ & $\begin{array}{c}151 \\
(43 \%)\end{array}$ & $\begin{array}{c}142 \\
(40.5 \%)\end{array}$ & $\begin{array}{l}\mathrm{P}< \\
0.001\end{array}$ \\
\hline $\begin{array}{l}\text { Modification in } \\
\text { Diets and Life } \\
\text { Style }\end{array}$ & $\begin{array}{c}257 \\
(73.2 \%)\end{array}$ & $\begin{array}{c}85 \\
(24.2 \%)\end{array}$ & $\begin{array}{c}9 \\
(2.6 \%)\end{array}$ & 0.004 \\
\hline $\begin{array}{l}\text { Good } \\
\text { Glycemic } \\
\text { and Diabetic } \\
\text { Control }\end{array}$ & $\begin{array}{c}264 \\
(75.2 \%)\end{array}$ & $\begin{array}{c}76 \\
(21.7 \%)\end{array}$ & $\begin{array}{c}11 \\
(3.1 \%)\end{array}$ & $\begin{array}{l}P< \\
0.001\end{array}$ \\
\hline $\begin{array}{l}\text { Laser Surgical } \\
\text { Procedures }\end{array}$ & $\begin{array}{c}114 \\
(32.5 \%)\end{array}$ & $\begin{array}{c}176 \\
(50.1 \%)\end{array}$ & $\begin{array}{c}61 \\
(17.4 \%)\end{array}$ & 0.91 \\
\hline $\begin{array}{l}\text { Intra Ocular } \\
\text { Injection } \\
\text { treatment }\end{array}$ & $\begin{array}{c}167 \\
(47.6 \%)\end{array}$ & $\begin{array}{c}141 \\
(40.2 \%)\end{array}$ & $\begin{array}{c}43 \\
(12.3 \%)\end{array}$ & 0.16 \\
\hline
\end{tabular}

Table-III. Knowledge about treatment options for diabetic retinopathy and its association with attitude

Total knowledge score for 14 knowledge questions was 20 (the maximum score). The mean knowledge score for our sample was $13.48+2.86$ and score range of 14 . A score of equal $<10$ was regarded as Poor Knowledge, Scores between 11 and 15 as Satisfactory Knowledge and scores $>16$ were regarded as having good knowledge about diabetic retinopathy. An independent t-test was used for group comparison of health facility, gender and family history with total knowledge score while ANOVA analysis was used to compare education level with the same. Detail of analysis is given in Table-IV. Male gender and higher education levels were found significantly associated with good knowledge about diabetic retinopathy.

\begin{tabular}{|c|c|c|c|c|}
\hline \multicolumn{2}{|c|}{ Variables } & $\mathbf{N}$ & Mean & P-Value \\
\hline \multirow{2}{*}{$\begin{array}{l}\text { Health } \\
\text { Facility }\end{array}$} & Public - HMC & 196 & 13.54 & \multirow{2}{*}{0.69} \\
\hline & Private - RMI & 155 & 13.41 & \\
\hline \multirow{2}{*}{ Gender } & Male & 229 & 13.73 & \multirow{2}{*}{0.02} \\
\hline & Female & 122 & 13.01 & \\
\hline \multirow{2}{*}{$\begin{array}{l}\text { Family } \\
\text { history }\end{array}$} & Yes & 267 & 13.51 & \multirow{2}{*}{0.77} \\
\hline & No & 84 & 13.40 & \\
\hline \multirow{7}{*}{$\begin{array}{l}\text { Education } \\
\text { Level }\end{array}$} & Uneducated & 153 & 12.92 & \multirow{7}{*}{$\begin{array}{c}P< \\
0.001\end{array}$} \\
\hline & Primary & 6 & 10.33 & \\
\hline & Secondary & 13 & 13.62 & \\
\hline & Matric & 40 & 13.30 & \\
\hline & Intermediate & 24 & 13.12 & \\
\hline & Graduate & 64 & 14.39 & \\
\hline & Post-graduate & 51 & 14.69 & \\
\hline
\end{tabular}

Mean Attitude Score in this study was $2.60+$ 1.25. The association of knowledge with attitude question; "Should a person with diabetes have regular eye checkup" and "Do you regard eye checkup as wastage of time and money" is significant at $P<0.001$, whereas the question "there is no need to visit ophthalmologist, if diabetes is in control" was not associated with knowledge about the diabetic retinopathy, the research groups differed in their opinion.

The correlation analysis between knowledge and attitude score shows a weak negative (- 0.16) relation between the two scores, statistically significant with a $\mathrm{p}$ - value of 0.002 .

Regarding the Practice, 126 (35.9\%) of the sample were on oral anti diabetics and 133 (38\%) were using both oral anti-diabetics and Insulin. $104(29.6 \%)$ were of the opinion that eye checkup shall be done immediately after diagnosis then six monthly, and 114 (32.5\%) said checkup shall be done when one suspects some eye problem.

In respondents 293 (83.5\%) out of 351 considers that an ophthalmologist shall be consulted incase if an eye problem develops, with 58 (16.5\%) remarked any doctor can be helpful in this situation.

The chi-square test between practice questions, how often eye check should be done and how 
often you go for eye checkup was found highly significant for groups with knowledge about diabetic retinopathy and positive family history (Table-V).

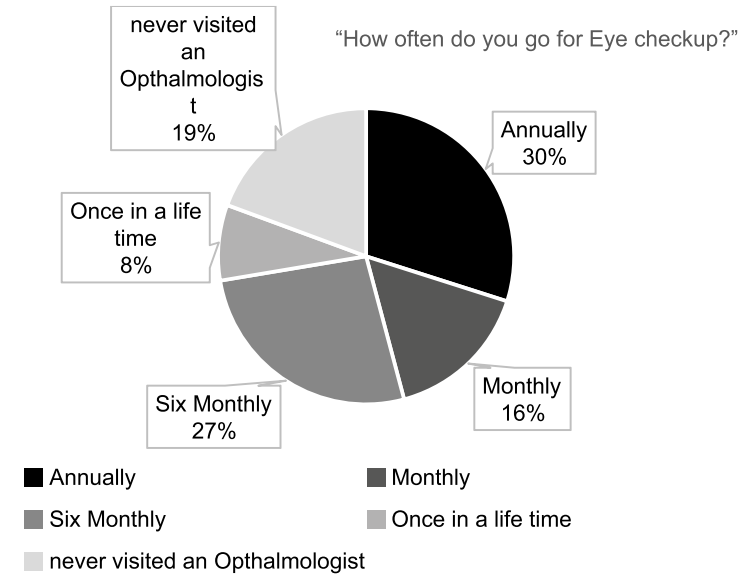

Figure-1. Details of the question; "How often do you go for Eye checkup?"

\begin{tabular}{|c|c|c|c|}
\hline \multirow[t]{2}{*}{$\begin{array}{l}\text { Family } \\
\text { History }\end{array}$} & \multirow{2}{*}{$\begin{array}{l}\text { Do you know } \\
\text { that diabetes } \\
\text { can cause } \\
\text { Diabetic } \\
\text { Retinopathy? }\end{array}$} & $\begin{array}{l}\text { how often eye } \\
\text { check should } \\
\text { be done * how } \\
\text { often you go for } \\
\text { eye checkup }\end{array}$ & \multirow[t]{2}{*}{ P- Value } \\
\hline & & $\begin{array}{l}\text { Pearson Chi- } \\
\text { Square }\end{array}$ & \\
\hline \multirow[b]{2}{*}{ NO } & No & 9.64 & 0.65 \\
\hline & Yes & 39.89 & $\begin{array}{l}\text { P-value } \\
<0.001\end{array}$ \\
\hline \multirow[b]{2}{*}{ YES } & No & 29.86 & 0.01 \\
\hline & Yes & 1.21 & $\begin{array}{l}\text { P-value } \\
<0.001\end{array}$ \\
\hline
\end{tabular}

Table-V. Chi- Square test between practice questions.

\section{DISCUSSION}

Diabetes Mellitus (DM) is the most prevalent non-communicable disease and a global public health concern. The incidence and prevalence of the disease is on the rise in Pakistan. Since it is a chronic disease, uncontrolled diabetic levels prone person to its complications. Out of 39 million global blindness, 1.8 million (4.8\%) is attributed to Diabetic Retinopathy. ${ }^{10}$

The risk of complications due to Diabetes in particular Diabetic Retinopathy can be reduced by good diabetic and blood pressure control, regular screening and laser treatment. ${ }^{11}$
The present study is hospital based, KAP study to ascertain the level of knowledge, attitude and practice of the admitted sample of diabetic patients in a public and private hospitals of district Peshawar. 351 diabetic patients were enrolled in the study with male to female ratio of 1.8:1.

In this study, $24.5 \%$ of the sample were regarded as having good knowledge. By good knowledge, it was meant that they were aware of diabetes, its risk factors and available treatment modalities. 16 $\%$ were having poor knowledge and $59 \%$ were having satisfactory level of knowledge about diabetes. This percentage of good knowledgeable diabetics about diabetic retinopathy, its risk factors and treatment options is approximately similar to the studies done in Karachi by Memon et al showing $35.2 \%{ }^{5}$, Indian studies by Rani et $\mathrm{al}^{12}$, and Hussain et $\mathrm{al}^{8}$ reported $37 \%$ and 40.7 $\%$ respectively. However, this percentage is low as compared to the study done on diabetics in Saudi Arabia with $75.6 \%$ of the population aware of diabetic retinopathy and its complications ${ }^{7}$, similar trend (72 \%) was observed in a study done on diabetics in Oman. ${ }^{13}$ In the current study, higher education level affected the knowledge score of the patients about diabetic retinopathy, and the association was found significant. This finding is similar to the studies done in India and Australia $^{13}$. Knowledge score categories i.e poor, satisfactory and good were not in agreement on the knowledge regarding treatment of diabetic retinopathy, only $24.5 \%$ of diabetics considered dietary and life style modification, and good glycemic control as a measure to control diabetes and diabetic retinopathy development and progression; similar results were noted for diabetics who regarded laser treatment as a modality to treat diabetic retinopathy. Results of this study are comparable to the study done in Oman showing that $18 \%$ of the study population knew about laser treatment (13), However, Rani et al who reported that $50 \%$ of the participants had knowledge about the treatment options, which is better than the results of this study. The studies done in Iran $^{14}$, Australia ${ }^{15}$ and Saudi Arabia ${ }^{16}$ showed similar knowledge trend about treatment options for diabetic retinopathy. 
The knowledge score categories were very closely related to attitude scores, although those with poor knowledge had better attitude than those with good knowledge. This explains the weak negative correlation point described in the result section, that knowledge was not correlated with attitude. Only one fourth of the study population had positive attitude, Hussain et al mentioned half of the study population having positive attitude in his study ${ }^{8}$, similar findings were reported by study in Oman ${ }^{13}$; however, this finding differs from the study concluded by Rani et al, who mentioned association of knowledge with positive attitude and practice. ${ }^{12}$

The Practice patterns seen in our population of diabetics reveal that $83 \%$ were of the opinion that ophthalmologist shall be consulted in case if some eye problem develops, and $66 \%$ respondents remarked that eye checkups shall be done immediately after diagnosis but only $30 \%$ got their checkup done on annual basis and $26.5 \%$ bi-annually. $20 \%$ never visited an ophthalmologist and $8 \%$ only once in their life time. Al Zarea in Saudi Arabia reported $95 \%$ of individuals going for regular eye checkups ${ }^{7}$ as compared to $72 \%$ in present study. These results were higher than the studies done by Memon et $\mathrm{al}^{5}$ and Khandekar et $\mathrm{al}^{13}$ where $57 \%$ visited ophthalmologist. The percentage of patients who never visited an ophthalmologist is also very high i.e $19 \%$, a study in India reported $14 \%$ noncompliant individuals who were not getting their periodic eye checkups. ${ }^{17}$

\section{STUDY LIMITATIONS}

Patients attending only two tertiary care hospitals of Peshawar were incorporated in this study, sample size was limited and only type 2 - diabetics were included in the study. Hence, results cannot be generalized onto the general population. The present study is providing the trends of knowledge, attitude and practice patterns of our patients. The questionnaire was close ended and hence, there was an element of "Leading Answers" in some parts of the questionnaire.

\section{CONCLUSION}

Blindness because of diabetic retinopathy resulting from uncontrolled diabetes is entirely preventable. The results of this study showed that female diabetic patients and illiterates were more prone to complications of diabetes than males and more educated counterparts. This effect was independent of their duration of diabetes and family history of diabetes. As in this study, Lack of knowledge cannot be compensated by positive attitude only. Hence, the need for Mass Awareness using population and high risk strategies is important to aware people about the hazards of diabetes and its complications.

Copyright $@ 20$ July, 2019.

\section{REFERENCES}

1. Association AD. Diagnosis and classification of diabetes mellitus. Diabetes Care. 2010; 33(1):S62-9.

2. World Health Organization (WHO) / International Diabetic Federation (IDF). Definition and diagnosis of diabetes mellitus and intermediate hyperglycemia [Internet]. World health organization. Geneva; 2006. Available from: http://www.who.int/diabetes/ publications/diagnosis_diabetes2006/en/index.html

3. Rahman Z, Khan I, Gaohar QY, Baig A, Khan FA. Level of awareness regarding diabetes and its management in diabetic population of Pakistan, and highlighting the role of consultant pharmacist. J Pak Med Assoc. 2014; 64(5):574-5.

4. Wadaani F Al. The knowledge attitude and practice regarding diabetes and diabetic retinopathy among the final year medical students of King Faisal University Medical College of Al Hasa region of Saudi Arabia: A cross sectional survey. Niger $\mathrm{J}$ Clin Pract [Internet]. 2013; 16(2):164-8. Available from: http://www.ncbi.nlm.nih.gov/pubmed/23563455

5. Memon MS, Shaikh SA, Shaikh AR, Fahim MF, Mumtaz $\mathrm{SN}$, Ahmed N. An assessment of knowledge, attitude and practices (KAP) towards diabetes and diabetic retinopathy in a suburban town of Karachi. Pak J Med Sci. 2015; 31(1):183-8.

6. Bressler N, Varma R, Doan Q V, Gleeson M, Danese M, Bower JK, et al. Underuse of the health care system by persons with diabetes mellitus and diabetic macular edema in the United States. JAMA Opthalmol. 2014; 132(2):168-73.

7. Al Zarea BK. Knowledge, attitude and practice of diabetic retinopathy amongst the diabetic patients of of AlJouf and Hail Province of Saudi Arabia. J Clin Diagnostic Res. 2016; 10(5):NC05-8. 
8. Hussain R, Rajesh B, Giridhar A, Gopalakrishnan M, Sadasivan S, James J, et al. Knowledge and awareness about diabetes mellitus and diabetic retinopathy in suburban population of a South Indian state and its practice among the patients with diabetes mellitus: A population-based study. Indian $\mathrm{J}$ Ophthalmol [Internet]. 2016;64:272-6. Available from: http://www. ijo.in/text.asp?2016/64/4/272/182937

9. Shilubane $H$, Netshikweta L, Ralineba T. Beliefs and practices of diabetic patients in Vhembe district of Limpopo Province. Afr J Prm Heal Care Fam Med. 2016;8(2):1-6.

10. World Health Organization. Global initiative for the elimination of avoidable blindness - action plan 2006-11. Geneva; 2007.

11. Li Z, Song Z, Wu S, Xu K, Jin D, Wang $H$, et al. Outcomes and barriers to uptake of cataract surgery in rural northern china: The heilongjiang eye study. Ophthalmic Epidemiol. 2014; $21(3): 161-8$.

12. Rani PK, Raman R, Subramani S, Perumal G, Kumaramanickavel G, Sharma T. Knowledge of diabetes and diabetic retinopathy among rural populations in India, and the influence of knowledge of diabetic retinopathy on attitude and practice. Rural Remote Health. 2008; 8(3):838.
13. Khandekar R, Al Harby S, Al Harthy H, Al Lawatti J. Knowledge, attitude and practice regarding eye complications and care among Omani persons with diabetes - A cross sectional study. Oman J Ophthalmol. 2010; 3(2):60.

14. Niroomand M, Ghasemi SN, Karimi-Sari H, KazempourArdebili S, Amiri P, Khosravi MH. Diabetes knowledge, attitude and practice (KAP) study among Iranian in-patients with type-2 diabetes: A cross-sectional study. Diabetes Metab Syndr Clin Res Rev [Internet]. 2016; 10(1):S114-9. Available from: http://dx.doi. org/10.1016/j.dsx.2015.10.006

15. Wong N, Wang SS, Lamoureux E, Wong TY, Tikellis G, Harper A, et al. Blood pressure control and awareness among patients with diabetes and hypertension attending a tertiary ophthalmic clinic. Diabet Med. 2009; 26(1):34-9.

16. Z Saadia, Rushdi S, Alsheha M, Saeed H, Rajab M. A study of knowledge attitude and practices of Saudi women towards diabetes mellitus. A (KAP) Study In Al-Qassim Region. Internet J Heal. 2009; 11(2):1-7.

17. Srinivasan NK, John D, Rebekah G, Kujur ES, Paul $P$, John SS. Diabetes and diabetic retinopathy: Knowledge, Attitude, Practice (KAP) among diabetic patients in a tertiary eye care centre. J Clin Diagnostic Res. 2017; 11(7):NC01-7.

\begin{tabular}{|c|c|c|c|}
\hline \multicolumn{4}{|c|}{ AUTHORSHIP AND CONTRIBUTION DECLARATION } \\
\hline Sr. \# & Author-s Full Name & Contribution to the paper & Author $=\mathbf{s}$ Signature \\
\hline 1 & Ali Raza & $\begin{array}{l}\text { Idea conception, Review and } \\
\text { manuscript editing. }\end{array}$ & \\
\hline 2 & Izma Khan & $\begin{array}{l}\text { Literature review, Data collection, } \\
\text { Entry and manuscript draft. }\end{array}$ & \\
\hline 3 & Haider Sami & $\begin{array}{l}\text { Data collection, Entry and data } \\
\text { analysis. }\end{array}$ & \\
\hline 4 & Amna Ejaz & Literature review, Data Entry and & \\
\hline 5 & Zunnoor Ahmed & $\begin{array}{l}\text { manuscript draft. } \\
\text { Data collection, Logistics, Entry. }\end{array}$ & 2. Ahmod \\
\hline
\end{tabular}

